\title{
CORRIGENDA
}

Comprehensive gene expression profiling and immunohistochemical studies support application of immunophenotypic algorithm for molecular subtype classification in diffuse large B-cell lymphoma: a report from the International DLBCL Rituximab-CHOP Consortium Program Study

C Visco, Y Li, ZY Xu-Monette, RN Miranda, TM Green, Y Li, A Tzankov, W Wen, W-m Liu, BS Kahl, ESG d'Amore, S Montes-Moreno, K Dybkær, A Chiu, W Tam, A Orazi, Y Zu, G Bhagat, JN Winter, H-Y Wang, S O'Neill, CH Dunphy, ED Hsi, XF Zhao, RS Go, WWL Choi, F Zhou, M Czader, J Tong, X Zhao, JH van Krieken, Q Huang, W Ai, J Etzell, M Ponzoni, AJM Ferreri, MA Piris, MB Møller, CE Bueso-Ramos, LJ Medeiros, L Wu and KH Young

Leukemia (2014) 28, 980; doi:10.1038/leu.2014.24

Correction to: Leukemia (2012) 26, 2103-2113; doi:10.1038/ leu.2012.83

Since the publication of this article, the authors have identified an omission in their paper, namely that important Supplementary Data was not included. These data are included in the Supplementary
File that accompanies the online version of this corrigendum. The supplementary information has also been included in the GSE website.

The authors would like to apologize for any inconvenience this may have caused.

\section{Criteria for diagnosis, staging, risk stratification and response assessment of multiple myeloma}

RA Kyle and SV Rajkumar

Leukemia (2014) 28, 980; doi:10.1038/leu.2014.11

Correction to: Leukemia (2009) 23, 3-9; doi:10.1038/leu.2008.291; published online 30 October 2008

Since the publication of this article, the authors have identified an error within Table 2, namely that the creatinine value
(Renal insufficiency: serum creatinine) was incorrectly listed as $1.73 \mathrm{mmol} / \mathrm{l}$. The correct value is $0.173 \mathrm{mmol} / \mathrm{l}$ (173 micromoles/l).

The authors would like to apologize for any inconvenience this may have caused. 